\title{
Stress response in mesoangioblast stem cells
}

\author{
F Geraci ${ }^{1,3}$, G Turturici ${ }^{1,3}$, D Galli ${ }^{2}$, G Cossu ${ }^{2}$, G Giudice ${ }^{1}$ and \\ G Sconzo ${ }^{*, 1}$ \\ ${ }^{1}$ Dipartimento di Biologia Cellulare e dello Sviluppo, Università di Palermo, \\ Palermo, Italy \\ 2 Stem Cell Research Institute, Dibit, H. San Raffaele, Milan, Italy \\ 3 These authors contributed equally to this work. \\ * Corresponding author: G Sconzo, Dipartimento di Biologia Cellulare e dello \\ Sviluppo, Viale delle Scienze, Palermo 90128 Italy. Tel: + 390916577416; \\ Fax: + 390916577430; E-mail: gasc@unipa.it
}

Received 05.4.05; revised 17.8.05; accepted 31.8.05; published online 11.11.05 Edited by RA Knight

\begin{abstract}
Stem cells are presumed to survive various stresses, since they are recruited to areas of tissue damage and regeneration, where inflammatory cytokines and cytotoxic cells may result in severe cell injury. We explored the ability of mesoangioblasts to respond to different cell stresses such as heat, heavy metals and osmotic stress, by analyzing heat shock protein (HSP)70 synthesis as a stress indicator. We found that the A6 mesoangioblast stem cells constitutively synthesize HSP70 in a heat shock transcription factor (HSF)-independent way. However, A6 respond to heat shock and cadmium treatment by synthesizing HSP70 over the constitutive expression and this synthesis is HSF1 dependent. The exposure of $A 6$ to copper or to a hypertonic medium does neither induce HSP70 synthesis nor activation of HSF1, while a constitutive binding of constitutive heat shock element binding factor was found. Together, these data suggest that mesoangioblasts constitutively express HSP70 as an 'a priori' activation mechanism, while they maintain the ability to respond to stress stimuli.

Cell Death and Differentiation (2006) 13, 1057-1063.

doi:10.1038/sj.cdd.4401794; published online 11 November 2005
\end{abstract}

Keywords: A6 stem cells; HSP70; CHBF; HSF1

Abbreviations: HSP, heat shock protein; HSF, heat shock transcription factor; HSE, heat shock element; $\mathrm{CHBF}$, constitutive heat shock element binding factor

\section{Introduction}

Cells respond to environmental, pathological and physiological stresses by inducing the synthesis of the heat shock proteins (HSP), which are highly conserved among all the organisms.

The transcription factor responsible for the stress-regulated synthesis is heat shock transcription factor (HSF)1. Under basal conditions, the inactive form of HSF1 is a phosphorylated monomer with no DNA binding and no transcriptional activity. In response to heat shock or other kinds of stresses,
HSF1 undergoes trimerization and becomes available for phosphorylation. $^{1-3}$ The heat shock proteins are classified into different families on the basis of molecular mass, and one of the most conserved is HSP70. As it can be induced by various stresses such as hyperthermia, oxidative stress, heavy metals and amino-acid analogs, it can be used as a stress marker. ${ }^{4,5}$ In mouse, the HSP70 family contains at least seven members, including two stress inducible proteins (HSP 70.1, HSP 70.3 $)^{6,7}$ called HSP70i and proteins constitutively expressed (HSC70, Grp78, Grp75). Moreover, two additional genes are developmentally regulated (hsp 70.2, hsc 70t). The inducible genes hsp70.1 and hsp70.3 are located in a tandem array on mouse chromosome $17^{8}$ and encode two almost identical proteins differing only at two residues, which for this reason cannot be distinguished from each other even by two-dimensional gel electrophoresis. ${ }^{9}$ Moreover, it has been demonstrated that in mouse embryo fibroblasts (MEF), both genes are induced at comparable extent by heat shock and other stresses such as cadmium treatment, whereas osmotic stress causes induction of just hsp70.1 gene and its absence cannot be compensated by hsp70.3. No induction is observed after oxidative stress. ${ }^{10-12}$ hsp70.1 is constitutively transcribed from one-cell stage to blastocyst stage, ${ }^{13}$ whereas hsp70.3 is constitutively expressed from two-cell stage. ${ }^{14}$

By the blastocyst stage, the expression of the two genes becomes heat inducible. In vitro, the protein HSP70-1/3 is expressed in four-cell embryos, morulae and blastocysts, and the inhibition of the genes by antisense oligonucleotides impairs embryo development, diminishing the ability of embryos to reach the blastocyst stage. ${ }^{9}$ Constitutive expression of Hsp70-1/3 is not observed after gastrulation, either in vivo or in cultured cells.

In this study, we investigated the ability of mouse A6 mesoangioblast stem cells to respond to various stressors including heat shock, heavy metals and hyperosmolarity. A6 cells are a clone of mesoangioblasts, recently characterized stem cells that were derived from the dorsal aorta of E9.5 mouse embryos and can be induced to differentiate into different mesodermal cell types such as muscle and bone. ${ }^{15,16}$

\section{Results and Discussion}

\section{Constitutive expression of the inducible HSP70}

Before studying the ability of the A6 mouse stem cells to respond to different cellular stresses, we tested the possibility that type I collagen, which is used as a substrate for cell culture, may itself induce stress, as previous data from Souren et $a l^{17}$ suggested that this collagen induces the synthesis of some heat stress proteins in the cultured cardiomyocites of newborn mice. To exclude this possibility, A6 cells were grown both with and without type I collagen. Western blot immunoassay with an antibody specific for the inducible HSP70 showed that A6 cells without any stress synthesize the inducible HSP70 in both conditions (Figure 1a, lanes 2, 1 respectively). Moreover, computer analysis showed that 
a

b

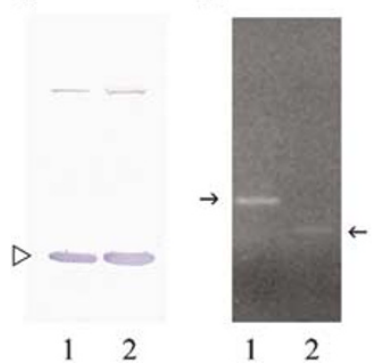

c

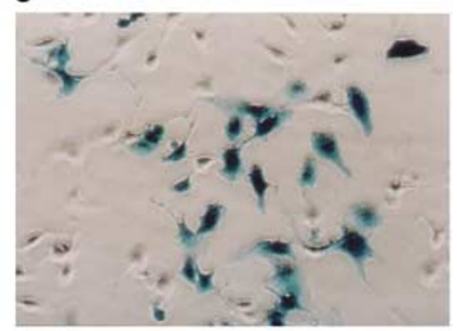

Figure 1 Inducible HSP70 synthesis under basal condition. (a) Western blot analysis of control cells grown with (lane 1) or without collagen (lane 2). Open triangle shows actin. The bands were quantified by Java Image software. The relative levels of Hsp70 were obtained as the sum of pixel values of each band divided by that of actin in the same lane (internal control). The data represent a typical result from three independent experiments. (b) Expression profile of hsp70.1 (lane 1) and of hsp70.3 (lane 2) mRNAs by RT-PCR. The arrows point the position of hsp70.1 and hsp70.3 mRNA. The RT-PCR product size for hsp70.1 is $291 \mathrm{bp}$ and for hsp70.3 is $230 \mathrm{bp}$. (c) $\beta$-Galactosidase staining of cells transfected with phsplacZ

HSP70 levels were not increased by type I collagen. This result demonstrates that HSP70 is constitutively expressed under physiological conditions in A6 stem cells, and collagen type I is not able to increase this synthesis.

In order to investigate whether both the inducible genes hsp70.1 and hsp70.3 were expressed in A6 stem cells, we assayed the presence of their mRNAs by RT-PCR of $3^{\prime}$ UTR, because this region shows low sequence similarity. ${ }^{8}$ We found that both genes were expressed in the absence of cellular stress (Figure 1b, lanes 1 and 2). Hsp70 expression was further confirmed by transfection assay with a plasmid containing the $\beta$-galactosidase reporter gene under the hsp70.3 gene promoter control (Figure 1c). No $\beta$-galactosidase activity was obtained when the cells were transfected as a control with a plasmid missing the hsp70.3 gene promoter (data not shown).

All these data demonstrate that $\mathrm{A} 6$ stem cells have a constitutive HSP70 expression which may protect them from sudden cellular stresses. In fact, it has been found that murine embryonic stem cells CGR8 are more resistant to oxidative stress and are highly proficient in the antioxidant defense, probably due to a constitutive expression of some inducible HSPs. ${ }^{18}$ On the contrary, central nervous system stem cells do not express HSP70 per se in the absence of stress. In consequence of mercury exposure, late differentiated astrocytes, differently from neurons, express HSP70, which protects them from the metal injury. ${ }^{19}$

\section{Response of $\mathbf{A 6}$ stem cells to different stresses}

We then investigated whether or not A6 cells were able to respond to various cell stresses, such as heat, heavy metal or osmotic stress, by further increasing inducible HSP70 synthesis. After the stresses, the cells were labeled with ${ }^{35} \mathrm{~S}$-methionine, and total protein lysates were observed by autoradiography after gel electrophoresis. In heat-treated cells, we noticed a band corresponding to HSP70 (Figure 2a, lane 2), which was absent in nontreated cells (Figure 2a, lane 1). The same result was obtained with high cadmium dose
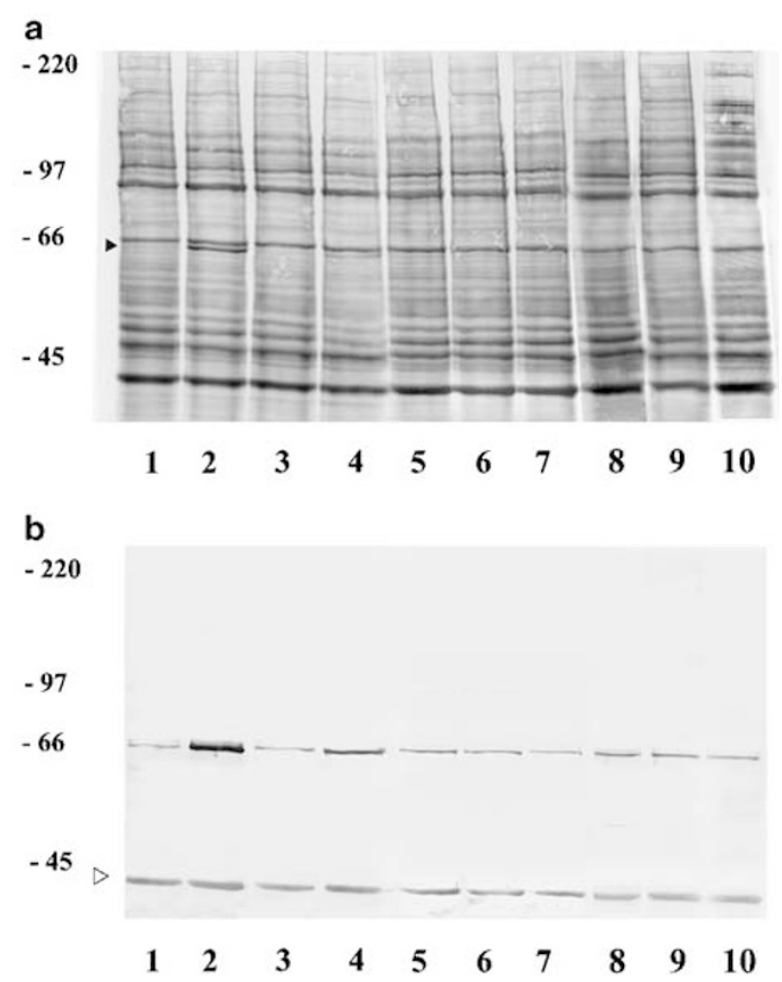

Figure 2 Induction of stress proteins in treated cells. (a) A6 stem cells were exposed $1 \mathrm{~h}$ at $42^{\circ} \mathrm{C}$ (lane 2), or were treated for $2 \mathrm{~h}$ with $40 \mu \mathrm{M}$ cadmium (lane 3), $2 \mathrm{~h}$ with $100 \mu \mathrm{M}$ cadmium (lane 4), $2 \mathrm{~h}$ with $200 \mu \mathrm{M}$ zinc (lane 5), $2 \mathrm{~h}$ with $200 \mu \mathrm{M}$ copper (lane 6), $24 \mathrm{~h}$ with $200 \mu \mathrm{M}$ copper (lane 7), 45 min with a 0.7 osM medium (lane 8), $2 \mathrm{~h}$ in $0.4 \mathrm{osM}$ medium (lane 9), $24 \mathrm{~h}$ in a $0.4 \mathrm{osM}$ medium (lane 10) and labeled for $3 \mathrm{~h}$ with ${ }^{35} \mathrm{~S}-L$-methionine. Protein pattern of control cells is shown in lane 1. Protein synthesis was observed immediately after methionine removal. Filled triangle shows Hsp70. Sizes are indicated in kilodaltons. A representative gel out of three experiments is shown. (b) Western blot analysis for HSP70 of control cells (lane 1), heat shock (lane 2), cadmium $40 \mu \mathrm{M}$ (lane 3), cadmium $100 \mu \mathrm{M}$ (lane 4), $2 \mathrm{~h}$ with $200 \mu \mathrm{M}$ zinc (lane 5), $2 \mathrm{~h}$ with $200 \mu \mathrm{M}$ copper (lane 6), $24 \mathrm{~h}$ with $200 \mu \mathrm{M}$ copper (lane 7 ), $45 \mathrm{~min}$ with a 0.7 osM medium (lane 8), $2 \mathrm{~h}$ in $0.4 \mathrm{osM}$ medium (lane 9), and $24 \mathrm{~h}$ in a 0.4 osM medium (lane 10)treated cells. The relative levels of Hsp70 were obtained as described in Figure 1. The results from three independent experiments were quantified. Sizes are indicated in kilodaltons

(Figure 2a, lane 4), while in low cadmium-, zinc-, or coppertreated cells, HSP70 synthesis was not observed (Figure 2a, lanes $3,5,6,7$, respectively). HSP70 synthesis was also undetectable in cells subjected to a hyperosmolar shock, a high saline treatment for a brief time (Figure 2a, lane 10), or to a moderately hypertonic treatment, for both a brief and a long time (Figure 2a, lanes 8 and 9).

We also examined HSP70 protein levels in treated cells. The induction was evaluated by Western blot immunoassays, using an antibody anti-HSP70, followed by computer analysis. The heated sample showed an increase of 4.9 -fold over the constitutive HSP70 synthesis of the control sample (Figure $2 b$, lanes 2 and 1, respectively). In the cadmiumtreated samples, the HSP70 increase was 0.5 -fold for the low dose and 3.9-fold for the high dose (Figure 2b, lanes 3, 4). No HSP70 increase was observed in zinc- and copper-treated cells for both a brief and a long time (Figure $2 b$, lanes 5, 6 and 7). Moreover, a brief treatment with a high or low dose of $\mathrm{NaCl}$ did not show any HSP70 increase (Figure $2 b$, lanes 5,6 ). On 
the contrary, an increase of 2.5-fold was evident with a prolonged low-dose salt treatment (Figure $2 \mathrm{~b}$, lane 7 ).

These findings suggest that if the rate of HSP70 synthesis is very low, the protein may not be visible after a short time of ${ }^{35} \mathrm{~S}$-methionine labeling, while it can be detected by immunoblot assay after a long time of treatment.

Together, these results indicate that both heat and cadmium are able to induce a rapid HSP70 response, while copper, zinc and the saline stress are not. A similar result for zinc treatment was observed in a particular clone of HeLa cells. ${ }^{20}$ On the other hand, a continuous osmotic stress for $24 \mathrm{~h}$ at a low saline dosage is able to induce a small increase in HSP70 synthesis.

\section{HSF-heat shock element (HSE) complexes in stressed stem cells}

As the HSP70 synthesis is regulated at transcriptional level, we analyze the HSE-binding activity by gel mobility shift assay. We found two different HSE-binding factors and their specificity was demonstrated by competition assays (data not shown). In unstressed cells, there was a constitutive HSEbinding activity (Figure $3 a$, lane 2 ). In heated, high cadmiumand zinc-treated cells, a different DNA-binding complex was evident (Figure 3a, lanes 3, 5 and 6). It could be easily distinguished, as the complex observed with extracts from control cells has a faster migration on the gel than the HSEHSF complex induced by heat shock, cadmium and zinc. At the same time, immunoblot assay with an anti-HSF1 antibody showed that heat, high cadmium and zinc treatment induced a slower migration of HSF1 on SDS-PAGE (Figure 3b, lanes 2, 4 and 5), compared with that of control cells (Figure $3 b$ lane 1). This result is consistent with previous work which demonstrated that, upon stress, HSF1 is hyperphosphorylated and retarded on gel; this phosphorylation is generally required to activate transcription. ${ }^{21}$ On the other hand, low cadmiumtreated samples showed the presence of both the DNAbinding complexes (Figure $3 a$, lane 4), and both forms of HSF1 were detected by antibody treatment (Figure $3 \mathrm{~b}$, lane 3). A different result was obtained with copper and with all the osmotic stresses. They all showed only the constitutive HSE-binding activity (Figure 3a, lanes 7-11), and immunoblot assay showed that HSF1 was not activated by phosphorylation (Figure 3b, lanes 6-10).

In summary, our results demonstrate that in A6 stem cells, there are two classes of HSE-binding factors: one is constitutive, while the other one is inducible by stresses and can be related to HSF. In untreated control cells and after copper and hyperosmolar treatment, the stress-induced HSF-binding activity is not detectable, and there is only a constitutive binding activity. On the contrary, heat, and high cadmium and zinc treatment induce the HSE-HSF-binding activity and the dissociation of the constitutive complex.

To study the stability of these HSE complexes, the binding reactions of control and heat-shocked cells were incubated at $25,37,43$ and $45^{\circ} \mathrm{C}$ and immediately loaded onto acrylamide gels. When the binding reaction was performed with extracts obtained from control cells, the shift to the highest temperature caused a rapid dissociation of the constitutive HSE

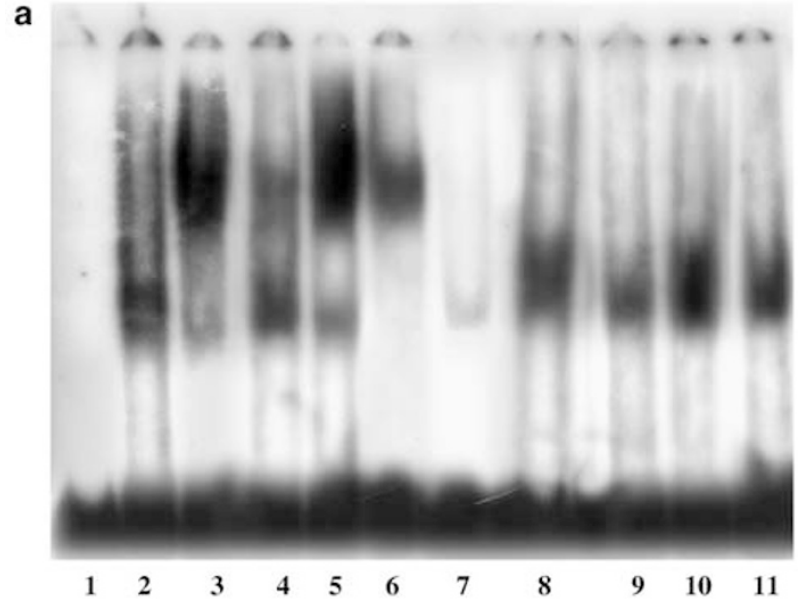

b -220

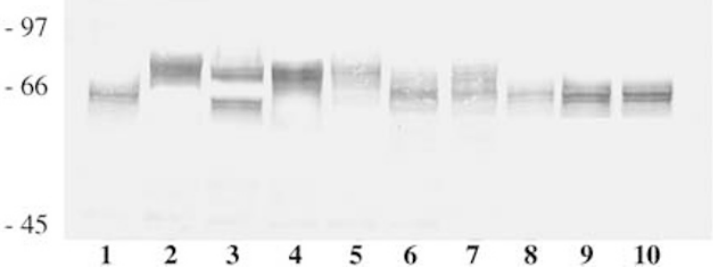

Figure 3 DNA-binding activity of HSFs in A6 treated cells. (a) EMSA were performed as described in the Materials and Methods section using total extracts from untreated (lane 2) and treated cells (lanes 3-11). Lane 1, free probe. Lane 3 , heat-shocked cells; lane 4, cadmium $40 \mu \mathrm{M}$-treated cells; lane 5 , cadmium $100 \mu \mathrm{M}$-treated cells; lane 6, zinc $200 \mu \mathrm{M}$-treated cells; lane 7, copper $200 \mu \mathrm{M}$ $2 \mathrm{~h}$-treated cells; lane 8, copper $200 \mu \mathrm{M} 24 \mathrm{~h}$-treated cells; lane 9, 0.7 osM; lane $10,0.4$ osM $2 \mathrm{~h}$ treated cells; lane $11,0.4$ osM $24 \mathrm{~h}$ treated cells. (b) Western blot analysis for HSF1 of control cells (lane 1), heat shock (lane 2), cadmium $40 \mu \mathrm{M}$ (lane 3), cadmium $100 \mu \mathrm{M}$ (lane 4), zinc $200 \mu \mathrm{M}$ (lane 5), copper $200 \mu \mathrm{M} 2 \mathrm{~h}$ (lane 6), copper $200 \mu \mathrm{M}$ (lane 7), 0.7 osM (lane 8), 0.4 osM $2 \mathrm{~h}$ (lane 9), $0.4 \mathrm{osM}$ $24 \mathrm{~h}$ (lane 100)-treated cells. A representative gel out of three experiments is shown. Sizes are indicated in kilodaltons

complexes (Figure 4, lanes 6, 8). On the contrary, if the binding reaction was performed with extracts obtained from heat-treated cells, the complex was stable up to $45^{\circ} \mathrm{C}$ (Figure 4, lanes 3, 5, 7, 9), even if there was a little decrease in its binding activity. Heat shock, as previously hypothesized, ${ }^{22}$ could alter HSF, allowing the formation of a more stable DNA complex. These results seem to confirm the differences between the basal HSE complex and the one that is inducible.

To determine the composition of the HSE-binding activity, both control and stressed cells were used to perform antibody perturbation assays using antibodies specific to HSF1 and HSF2. Both antibodies did not seem to interfere with the constitutive complex formation in unstressed A6 stem cells (Figure 5a, lanes 1-3), indicating that neither HSF1 nor HSF2 is involved in this complex. A similar complex has been found in other cell lines, such as HeLa and rodent cells $\mathrm{CHO}$, and it was termed constitutive HSE-binding factor, CHBF. It was also observed that both the activation of HSF1 and the dissociation of CHBF were required to activate HSP70 synthesis under stress conditions. ${ }^{23,24}$ This result, taken 


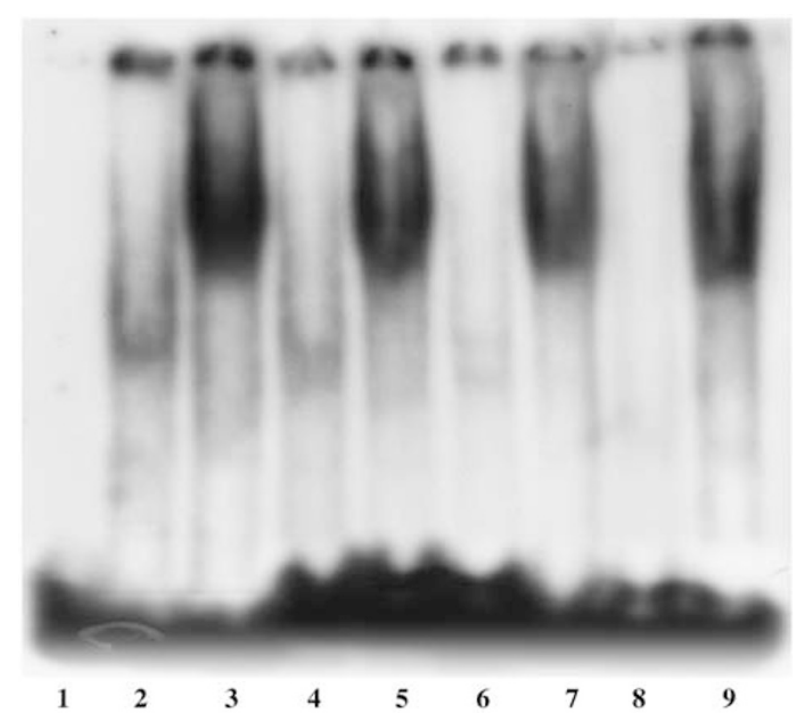

Figure 4 HSE-binding complex formation at different temperatures. Gel shift assays were performed with extracts prepared from control cells (lanes 2, 4, 6 and 8) and from cells heated at $42^{\circ} \mathrm{C}$ for $1 \mathrm{~h}$ (lanes 3,5,7 and 9). Binding reactions were performed for $20 \mathrm{~min}$ at $25^{\circ} \mathrm{C}$ (lanes $2-3$ ), $20 \mathrm{~min}$ at $37^{\circ} \mathrm{C}$ (lanes 4-5), $20 \mathrm{~min}$ at $43^{\circ} \mathrm{C}$ (lanes $6-7$ ) and $20 \mathrm{~min}$ at $45^{\circ} \mathrm{C}$ (lanes 8-9). Lane 1, free probe

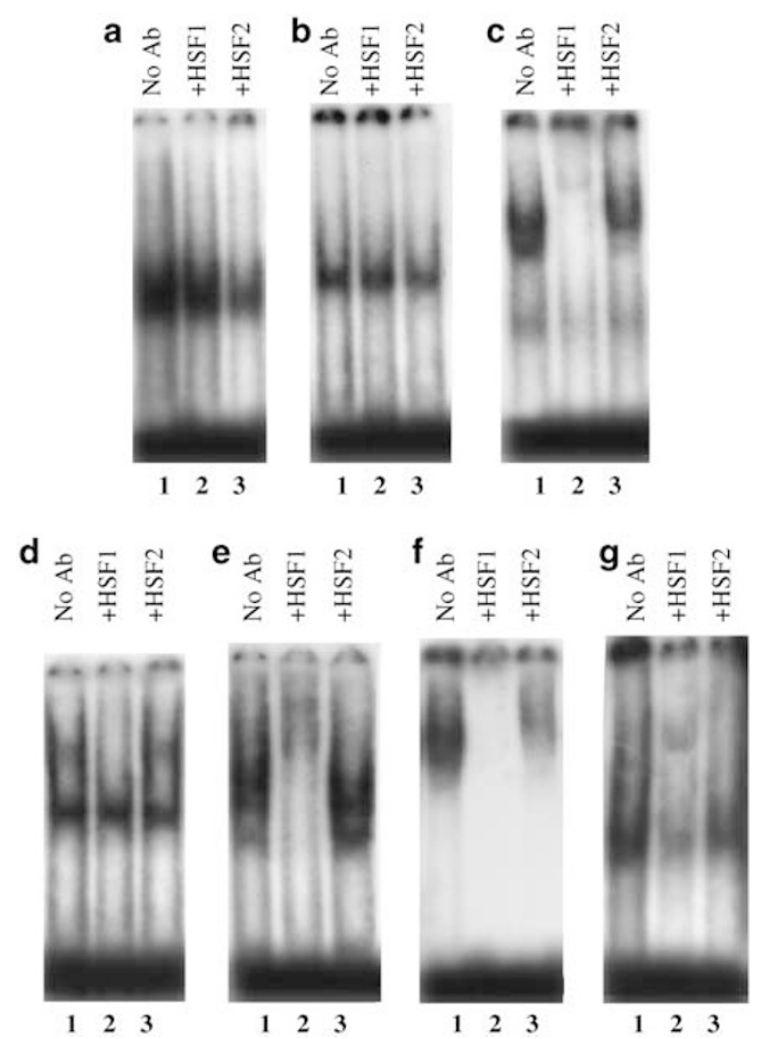

Figure 5 Effect of anti-HSF1 and HSF2 antibody on the migration of DNAprotein complexes with extracts from treated cells. Anti-HSF1 (lane 2) or antiHSF2 antibodies (lane 3) were incubated with $45 \mu \mathrm{g}$ of cell extracts. No antibody added (lane 1). (a) Untreated cells. (b) Salt-treated cells. (c) Heat-treated cells. (d) Cadmium $40 \mu \mathrm{M}$-treated cells. (e) Cadmium $100 \mu \mathrm{M}$-treated cells. (f) Zinc $200 \mu \mathrm{M}$-treated cells. (g) Copper $200 \mu \mathrm{M} 24 \mathrm{~h}$-treated cells. A representative gel out of three experiments is shown together with the phosphorylation state of HSF1, seems to exclude that in A6 stem cells the constitutive HSP70 synthesis depends on HSF1. We therefore suggest that in A6 stem cells, the constitutive HSP70 expression may be regulated by basal transcription factors that are different from HSFs. The role of the constitutive HSP70 expression remains to be clarified. In saline-treated samples, a result similar to that of control sample was obtained. In fact, the antibodies of both HSFs did not affect the migration or the formation of the $\mathrm{CHBF}$ complex (Figure 5b, lanes 1-3). Moreover, after all treatments, HSF1 was not hyperphosphorylated and this may be related to the absence of an inducible HSP70 synthesis. As expected, in heated, and in high cadmium-treated cells, anti-HSF2 antibody did not interfere in HSE complex formation, while addition of anti-HSF1 antibody to the reaction retarded complex migration (Figure $5 \mathrm{c}$ and e, lanes 3 and 2, respectively). A different result was obtained with cells treated with a low cadmium dosage. Anti-HSF2 antibody did not interfere either with the slow or the fast migrating HSE complex (Figure $5 \mathrm{~d}$, lane 3), whereas anti-HSF1 antibody was able to interfere only with the barely visible slow-migrating HSE complex (Figure 5d, lane 2). This result was correlated with the presence of the activated HSF1 form in the lysates. Therefore, we suggest that the stress-induced HSE-HSF binding alone is not sufficient to activate hsp70 synthesis. A different result was also obtained with zinc and copper. In zinc-treated cells, the addition of anti-HSF1 antibody completely neutralized the HSE-binding activity (Figure $5 f$, lane 2 ), and what is more, a partial reduction of the binding activity was also observed by using the anti-HSF2 antibody (Figure 5f, lane 3 ). On the contrary, in copper-treated cells, the addition of anti-HSF2 antibody did not interfere on the HSE complex formation, while addition of anti-HSF1 antibody to the reaction retarded complex migration (Figure $5 \mathrm{~g}$ ). These results suggested that the copper-induced HSE-binding activity was composed of HSF1, even though it was not hyperphosphorylated, as demonstrated by immunoblot assays (Figure 3b, lane 7). We can hypothesize that copper induces HSF1 trimerization in A6 stem cells but not its hyperphosphorylation, as it has been demonstrated for salycilate. ${ }^{25}$

Our results show that $\mathrm{A} 6$ stem cells, despite the constitutive expression of HSP70, are able to respond rapidly to heat and high cadmium stresses with the typical cellular response with the HSP70 synthesis. On the other hand, other kinds of metals and the osmotic stress, also at a high dosage, are not able to induce this response.

\section{Transcriptional activation of an episomic hsp70 promoter in control and in stressed A6 stem cells}

To better evaluate our data, A6 stem cells were transfected both with phsplacZ and with a point-mutated HSE phsplacZ. $\beta$-Galactosidase expression was measured and transfection efficiency was monitored by cotransfection with pCAT-control vector. $\beta$-Galactosidase activity was expressed in terms of ratio to CAT activity. Transfected cells were grown under basal conditions or subjected to stresses. $\beta$-Galactosidase expression in A6 cells, subjected to heat shock or cadmium, increased with respect to constitutive expression of unstressed cells (Table 1). This increase is in agreement with 
Table 1 Transient expression of construct phsplacZ and its derivates in A6 transfected cells

\begin{tabular}{lcc}
\hline & \multicolumn{2}{c}{$\boldsymbol{\beta}$-gal activity (arbitrary units) } \\
\cline { 2 - 3 } Sample & phsplacZ & MutHSEphsplacZ (\%) \\
\hline Control & 1.0 & 52 \\
Heat shock & 3.0 & 17.3 \\
Cadmium $100 \mu \mathrm{M}$ & 1.53 & 24 \\
Zinc 200 $\mu \mathrm{M}$ & 1.07 & 66 \\
Copper 200 $\mu \mathrm{M} \mathrm{2h}$ & 0.93 & 56.7 \\
Copper 200 $\mu \mathrm{M} 24 \mathrm{~h}$ & 0.95 & 44.1 \\
0.4 osM 24h & 1.1 & 49.3 \\
\hline
\end{tabular}

the HSP70i increase over the basal expression, observed by immunoblot assays and with HSP70 ${ }^{35}$ S-methionine synthesis. Moreover, mutation of the HSE consensus significantly decreased the episomic hsp70 expression after heat and cadmium treatment (Table 1), demonstrating that HSE consensus is essential for heat shock and also for cadmium cellular response. A less severe ( $\sim 50 \%)$ inhibiting effect of construct expression was observed in unstressed cells. This datum demonstrates that HSE consensus, and probably $\mathrm{CHBF}$, which binds the consensus in vitro, plays a positive role in hsp70 promoter transcription also under basal growth conditions. In zinc-, copper- and osmolarity-treated cells, hsp70 mutated promoter activity was similar to that obtained for unstressed cells. No differences were observed in the episomic expression of phsplacZ, confirming the data of metabolic labeling. All these data together indicate that heat shock and cadmium induce an increase over the basal expression of HSP70 synthesis, whereas all the other kinds of stresses that we tried do not, and we can observe only constitutive expression of the protein. In both cases, the HSE consensus is more or less involved in constitutive or inducible HSP70 expression.

In conclusion, our data show a complex and diversified stress response in mesoangioblasts; intriguingly, these cells constitutively express HSP70, while other stem cells, such as adult neural stem cells, do not, and this may relate to a functional requirement for stem cells that migrate on areas of necrosis and inflammation. Although constitutive synthesis of HSP70 was observed in ES, ${ }^{18}$ this is the first evidence that a stem cell, derived from postimplantation embryo, shows constitutive HSP70 expression, much like preimplantation embryos. It will be of interest in the future to test whether mesoangioblasts derived from adult tissues ${ }^{26}$ or other types of fetal and adult stem cells show this peculiar feature.

\section{Materials and Methods}

\section{Cell culture, heat shock, heavy metals and hypertonic treatment}

Mouse A6 stem cells were grown on collagen I-treated plates in Dulbecco modified Eagle's medium (DMEM) (Euroclone) supplemented with $10 \%$ fetal bovine serum in a humidified $5 \% \mathrm{CO}_{2}$ atmosphere at $37^{\circ} \mathrm{C}$. For heat shock, plates were sealed with parafilm and immersed for $1 \mathrm{~h}$ in a $42^{\circ} \mathrm{C}$ water bath. Cells were alternatively treated with 40 or $100 \mu \mathrm{M}$ cadmium sulfate for $2 \mathrm{~h}, 200 \mu \mathrm{M}$ zinc sulfate for $2 \mathrm{~h}$, and $200 \mu \mathrm{M}$ copper sulfate for 2 and $24 \mathrm{~h}$. For hypertonic stress, cells were grown in a 0.7 osM medium for
$45 \mathrm{~min}$, or in a $0.4 \mathrm{osM}$ medium for 2 or $24 \mathrm{~h}$ (the desired osmolarity of the medium was reached by adding $\mathrm{NaCl}$ ).

\section{Trypan blue dye exclusion}

To measure viability, cells were stained with trypan blue dye and then counted, as described elsewhere. ${ }^{27}$

\section{Preparation of protein extracts}

PBS-washed cells were resuspended in lysis buffer $(20 \mathrm{mM}$ Hepes, $\mathrm{pH}$ 7.9; $0.4 \mathrm{M} \mathrm{NaCl} ; 0.2 \mathrm{mM}$ EDTA; $10 \%$ glycerol; $0.5 \mathrm{mM}$ dithiothreitol; $0.5 \mathrm{mM}$ PMSF) and lysed by three cycles of freezing (liquid nitrogen) and thawing $\left(37^{\circ} \mathrm{C}\right.$ water bath). Cell debris were removed by centrifugation at $12000 \times g$ for $30 \mathrm{~min}$ at $4^{\circ} \mathrm{C}$. Protein concentrations of extracts were determined by Folin and Ciocalteau reagent, according to the Lowry method. $^{28}$

\section{Western blot (immunoblot) analysis}

Whole-cell extracts $(70 \mu \mathrm{g})$ were subjected to a $10 \%$ SDS-PAGE and transferred to an ECL-Hybond membrane (Amersham) using a minielectroblot (Biorad).

After blocking for $2 \mathrm{~h}$ in $5 \%$ nonfat dry milk in TBST buffer (10 mM Tris$\mathrm{HCl}, \mathrm{pH} 7.5,150 \mathrm{mM} \mathrm{NaCl}, 0.2 \%$ Tween 20), the membranes were incubated for $1 \mathrm{~h}$ with rabbit polyclonal anti-Hsp70 (1:10000 dilution; Calbiochem), rat anti-HSF1 (1:1500 dilution; Neomarkers) and mouse anti-actin (1:1500 dilution; Neomarkers). Alkaline phosphatase-conjugated anti-rabbit, anti-mouse and anti-rat (1:5000 dilution; Promega) were used as secondary antibody.

\section{Gel mobility shift assay}

Whole-cell extracts containing $45 \mu \mathrm{g}$ of protein were incubated with a double-stranded $\gamma^{32}{ }^{32}$-labeled HSE oligonucleotide (5'-GGGGTCAGAA TATTCTAGAATATTCTAGAATGGGTCAGG- $3^{\prime}$ ) in $30 \mu \mathrm{l}$ of a solution containing $10 \mathrm{mM}$ Hepes, pH 7.9; $10 \mathrm{mM} \mathrm{KCl} ; 50 \mathrm{mM} \mathrm{NaCl} ; 1.5 \mathrm{mM} \mathrm{MgCl}_{2}$ and $10 \%$ glycerol. The samples were incubated at $25^{\circ} \mathrm{C}$ for $20 \mathrm{~min}$. The HSE-containing complexes were analyzed on $4 \%$ nondenaturing polyacrylamide gels. For antibody perturbation experiments to analyze HSF1 and HSF2 composition in the HSE-binding activities both in cells grown under basal conditions or differently treated, dilution of either antiHSF1 or anti-HSF2 antibody (Neomarkers) was incubated with the reaction mixture for $1 \mathrm{~h}$ at $25^{\circ} \mathrm{C}$ with the labeled probe.

\section{mRNA isolation and RT-PCR}

mRNA was obtained by using the mRNA isolation kit (Roche) according to the manufacturer's instructions. Oligos used for the amplification of the following genes were hsp70.1 (291 bp) sense $5^{\prime}$-TGCTTGGGCACCGAT TACTGTCAA- $3^{\prime}$ and antisense $5^{\prime}$-GGCAGCTAGACTATATGTCTTCC CAGGCTACTG-3'; hsp70.3 (230 bp) sense 5'-AGATATGTGGCCTTGA GGACTGTCATTATTTC- $3^{\prime}$ and antisense $5^{\prime}$-CAAATCACATCAGCGGG GCAGTGCTGAATTG-3'. RT-PCR was performed with the Supercript One-Step RT-PCR kit (Invitrogen).

\section{Metabolic labeling with ${ }^{35}$ S-methionine}

Cells were incubated in a methionine-free medium (Sigma) containing $10 \%$ fetal bovine serum and exposed to stress treatment. After the 
treatment, $20 \mu \mathrm{Ci} / \mathrm{ml}$ of ${ }^{35} \mathrm{~S}-\mathrm{L}-$ methionine $(1000 \mathrm{Ci} / \mathrm{mM}$, Amersham) was added and cells were labeled for $3 \mathrm{~h}$. The incorporation of ${ }^{35} \mathrm{~S}-\mathrm{L}$ methionine into proteins was determined by trichloroacetic acid precipitation. Whole-cell extracts containing $30 \mu \mathrm{g}$ of proteins were analyzed by $10 \%$ SDS-PAGE and fluorography.

\section{Transfection and $\beta$-galactosidase assay}

For transfection, cells were dispensed into 12-well plates and left for $48 \mathrm{~h}$. Experiments were carried out using a promoter-report construct which contained an Escherichia coli lacZ gene driven by $620 \mathrm{bp}$ of promoter gene from the murine hsp70.3 gene (phsplacZ). ${ }^{29}$ phsplacZ $(0.5 \mu \mathrm{g})$ was transfected into the cells by FUGENE. After $48 \mathrm{~h}$, cells were fixed with $4 \%$ paraformaldehyde for $30 \mathrm{~min}$ at room temperature and washed twice with PBS. $\beta$-Galcatosidase was detected by incubating the cells for $24 \mathrm{~h}$ at $37^{\circ} \mathrm{C}$ in $1 \mathrm{mg} / \mathrm{ml}$ 5-bromo-4-chloro-3-indolyl $\beta$-D-galactoside $\mathrm{x}$-gal (Sigma); $40 \mathrm{mM}$ citric acid/Na phosphate buffer, $\mathrm{pH} 6.0 ; 5 \mathrm{mM} \mathrm{K}{ }_{4} \mathrm{Fe}(\mathrm{CN})_{6} ; 5 \mathrm{mM}$ $\mathrm{K}_{3} \mathrm{Fe}(\mathrm{CN})_{6} ; 150 \mathrm{mM} \mathrm{NaCl}$ and $2 \mathrm{mM} \mathrm{MgCl}_{2}$.

\section{$\beta$-Galactosidase and cloramphenicol acetyltransferase (CAT) reporter assay}

A6 cells were cotransfected with phsplacZ and with pCAT-control Vector (Promega) into six-well plates. In total, $2 \mu \mathrm{g}$ of each plasmid was used for the transfection. Where indicated, phsplacZ with a mutation in HSE consensus was used. After $48 \mathrm{~h}$, cells were washed three times with PBS and then air-dried. Cells were lysed by adding $0.65 \%$ NP40; $10 \mathrm{mM}$ Tris$\mathrm{HCl}, \mathrm{pH} 8.0 ; 1 \mathrm{mM}$ EDTA, pH 8.0 and $150 \mathrm{mM} \mathrm{NaCl}$. After 5 min, the lysis buffer containing cytoplasmic proteins was centrifuged at $12000 \times g$ for $1 \mathrm{~min}$ at $4^{\circ} \mathrm{C}$. Lysate, $30 \mu \mathrm{l}$, was used both for $\beta$-galactosidase and CAT assay. To measure the $\beta$-galactosidase activity, $204 \mu \mathrm{l}$ of $1 \mathrm{mM} \mathrm{MgCl}$, $45 \mathrm{mM} \beta$-mercaptoethanol, $66 \mathrm{mM} \mathrm{Na}_{2} \mathrm{HPO}_{4}$ and $66 \mu$ l of o-nitrophenyl- $\beta$ D-galactopiranoside $(4 \mathrm{mg} / \mathrm{ml})$ were added to the sample. The sample was incubated overnight at $37^{\circ} \mathrm{C}$ and after the addition of $500 \mu \mathrm{l} \mathrm{Na}_{2} \mathrm{Co}_{3} 1 \mathrm{M}$ $\beta$-galactosidase was quantified by using a spectrophotometer $(420 \mathrm{~nm})$.

For CAT assay, samples were incubated $5 \mathrm{~min}$ at $68^{\circ} \mathrm{C}$. To each was added $70 \mu \mathrm{l}$ of a mix containing $20 \mu \mathrm{l} 8 \mathrm{mM}$ cloramphenicol, $20 \mu \mathrm{l} 0.5 \mathrm{mM}$ Acetil-Coenzime A, $30 \mu \mathrm{l} 250 \mathrm{mM}$ Tris- $\mathrm{HCL}, \mathrm{pH} 7.8$, and $2 \mu \mathrm{l}{ }^{14} \mathrm{C}$-AcetilCoenzime A ( $54 \mathrm{mCi} / \mathrm{mmole})$. The samples were incubated for $2 \mathrm{~h}$ at $37^{\circ} \mathrm{C}$. Acetylated cloramphenicol was obtained by extraction with ethyl acetate. ${ }^{14} \mathrm{C}$ incorporation was measured. The results from three independent experiments were quantified.

\section{Acknowledgements}

We thank Franco Mangia and Arturo Bevilacqua for the kind gift of the plasmid phsplacZ and its mutated form. This research was supported by Italian Murst (60\%).

\section{References}

1. Morimoto RI (1998) Regulation of the heat shock transcriptional response: cross talk between a family of heat shock factors, molecular chaperones, and negative regulators. Genes Dev. 12: 3788-3796

2. Holmberg Cl, Hietakangas V, Mikhailov A, Rantanen JO, Kallio M, Meinander A, Hellman J, Morrice N, MacKintosh C, Morimoto RI, Eriksson JE and Sistonen $L$ (2001) Phosphorylation of serine 230 promotes inducible transcriptional activity of heat shock factor 1. EMBO J. 20: 3800-3810
3. Voellmy R (2004) On mechanism that control heat shock transcription factor activity in metazoan cells. Cell Stress Chaperones 9: 122-133

4. Mukhopadhyay I, Nazir A, Safena DK and Chowdhuri DK (2003) Heat shock response: hsp70 in environmental monitoring. J. Biochem. Mol. Toxicol. 17: 249-254

5. Nollen EA and Morimoto RI (2002) Chaperoning signaling pathways: molecular chaperones as stress-sensing 'heat shoch' proteins. J. Cell Sci. 115: 2809-2816

6. Hunt C and Calderwood S (1990) Characterization and sequence of a mouse hsp70 gene and its expression in mouse cell lines. Gene 87: 199-204

7. Perry MD, Adjame L, Shtang S and Moran LA (1994) Structure and expression of an inducible hsp70-encoding gene from Mus musculus. Gene 146: $273-278$

8. Hunt CR, Gasser DL, Chaplin DD, Pierce JC and Kozak CA (1993) Chromosomal localization of five murine HSP70 gene family members: Hsp70-1, Hsp70-2, Hsp70-3, Hsc70t, and Grp78. Genomics 16: 193-198

9. Dix DJ, Garges JB and Hong RL (1998) Inhibition of hsp70-1 and hsp70-3 expression disrupts preimplantation embryogenesis and heightens embryo sensitivity to arsenic. Mol. Reprod. Dev. 51: 373-380

10. Lee JS and Seo JS (2002) Differential expression of two stress-inducible hsp70 genes by various stressors. Exp. Mol. Med. 34: 131-136

11. Fiorenza MT, Bevilacqua A, Canterini S, Torcia S, Pontecorvi M and Mangia $F$ (2004) Early transcriptional activation of the Hsp70.1 gene by osmotic stress in one-cell embryos of the mouse. Biol. Reprod. 70: 1606-1613

12. Shim EH, Kim JI, Bang ES, Heo JS, Lee JS, Kim EY, Lee JE, Park WY, Kim SH, Kim HS, Smithies O, Jang JJ, Jin DI and Seo JS (2002) Targeted disruption of hsp70.1 sensitizes to osmotic stress. EMBO Rep 3: $857-861$

13. Hahnel AC, Gifford DJ, Heikkila JJ and Schultz GA (1986) Expression of the major heat shock protein (hsp70) family during early mouse embryo development. Teratog. Carcinog. Mutagen. 6: 493-510

14. Christians E, Campion E, Thompson EM and Renard J (1995) Expression of the HSP70.1 gene, a landmark of early zygotic activity in the mouse embryo, is restricted to the first burst of transcription. Development 121: 113-122

15. Minasi MG, Riminucci M, De Angelis L, Borello U, Berarducci B, Innocenzi $A$, Caprioli A, Sirabella D, Baiocchi M, De Maria R, Boratto R, Jaffredo $T$, Broccoli V, Bianco P and Cossu G (2002) The meso-angioblast: a multipotent, self-renewing cell that originates from the dorsal aorta and differentiates into most mesodermal tissues. Development 129: 27732783

16. Cossu $G$ and Bianco P (2003) Mesoangioblasts - vascular progenitors for extravascular mesodermal tissues. Curr. Opin. Genet. Dev. 13: 537-542

17. Souren JEM, Van Schoot MCC and Van Wijk R (1995) HSP synthesis of neonatal rat heart is regulated by a collagen environment. Int. J. Hyperthermia 11: $257-266$

18. Saretzki G, Armstrong L, Leake A, Lako M and von Zglinicki T (2004) Stress defense in murine embryonic stem cells is superior to that of various differentiated murine cells. Stem Cells 22: 962-971

19. Cedrola S, Guzzi GP, Ferrari D, Gritti A, Vescovi AL, Pendergrass JC and La Porta AM (2003) Inorganic mercury changes the fate of murine CNS stem cells. FASEB J. 17: 869-871

20. Cigliano S, Remondelli P, Minchiello L, Mellone MC, Martire G, Monatti S and Leone A (1996) Analysis of metal-regulated metallothionein and heat shock gene expression in HeLa derived cadmium-resistent cells. Exp. Cell Res. 228: 173-180

21. Xia W and Voellmy R (1997) Hyperphosphorylation of heat shock transcription factor 1 is correlated with transcriptional competence and slow dissociation of active factors trimers. J. Biol. Chem. 272: 4094-4102

22. Mosser DD, Theodorakis NG and Morimoto RI (1988) Coordinate changes in heat shock element binding activity and HSP70 gene transcription rates in human cells. Mol. Cell Biol. 8: 4736-4744

23. Kim D, Ouyang H, Yang SH, Nussenzweig A, Burgman P and Li GC (1995) A constitutive heat shock element-binding factor is immunologically identical to the Ku autoantigen. J. Biol. Chem. 270: 15277-15284

24. Liu RY, Corry PM and Lee YJ (1995) Potential involvement of a constitutive heat shock element binding factor in the regulation of chemical stress-induced hsp70 gene expression. Mol. Cell Biochem. 144: 27-34

25. Jurivich DA, Pachetti C, Qiu L and Welk JF (1995) Salicylate triggers heat shock factor differently than heat. J. Biol. Chem. 270: 24489-24495 
26. Sampaolesi M, Torrente $Y$, Innocenzi A, Tonlorenzi R, D'Antona G, Pellegrino MA, Barresi R, Bresolin N, Cusella De Angelis MG, Campbell KP, Bottinelli R and Cossu G (2003) Cell therapy of alpha sarcoglycan null dystrophic mice through intra-arterial delivery of mesoangioblasts. Science 301: 487-492

27. McClowskey TW, Chavan S, Lakshmi Tamma SM and Pahwa S (1998) Comparison of seven quantitative assays to assess lymphocytic cell death during HIV infection: measurement of induced apoptosis in anti-Fas treated
Jurkat cells and spontaneous apoptosis in peripheral blood mononuclear cells from children infected with HIV. AIDS Res. Hum. Retroviruses 14: 1413-1422

28. Lowry OH, Rosebrough NJ, Farr AL and Randall RJ (1951) Protein measurement with the Folin Phenol reagent. J. Biol. Chem. 193: 265-275

29. Bevilacqua A, Fiorenza MT and Mangia F (1997) Developmental activation of an episomic hsp70 gene promoter in two-cell mouse embryos by transcription factor Sp1. Nucleic Acids Res. 25: 1333-1338 